\title{
PENGARUH TERAPI MUSIK TERHADAP PENURUNAN TINGKAT KECEMASAN PADA ANAK YANG DIRAWAT DI RUMAH SAKIT Dr.OEN SURAKARTA
}

\author{
Oleh : \\ Rahayu Setyaningsih ${ }^{1}$ Sri Aminingsih ${ }^{2}$ Linda Yuni Hastari ${ }^{3}$
}

\begin{abstract}
Background. Hospitalization is a process that for some reason or emergency plans, so the children had to be hospitalized can cause children to experience anxiety. To overcome anxiety management can be given psychotherapy, one of which is with music therapy. Based on the data obtained through patient registration book entry of data obtained that the number of pediatric patients aged 3-6 years who were admitted to Teratai Ward. Dr. Oen Surakarta in September amounted to 43 children, with the number 5 top disease was observed febrile illness ( 14 children), abdominal pain ( 5 children), vomiting (5 children), DHF ( 5 children) and bronchopneumonia (4 children).

The research objective of this study was to determine the effect of music therapy to decrease the level of anxiety in children who were treated at the Dr. Oen Surakarta Hospital before and after the given music therapy.

Research method The research used in this study is the approach Quasy Experiment with one group pre-test and post-test. Using purposive sampling with a sample size of 30 children. Collecting data using the observation sheet in the form of a checklist.

Results: The results of the analysis using dependent test paired samples Ttest SPSS version 18.0 with $\alpha=5 \%(0.05)$, obtained results show $21312 \mathrm{t}$ with $p$ value of 0:00. so $p$ value of $<0.05$., which means that there is an influence of music therapy to decrease the level of anxiety in children who were treated at the Hospital Dr. Oen Surakarta.

Conclusion: There is a decrease in the effect of music therapy on anxiety levels in children who were treated at the Dr. Oen Surakarta Hospital.
\end{abstract}

Keywords : Music Therapy, Anxiety, Hospitalization.

\section{PENDAHULUAN}

Perawatan anak di rumah sakit membuat anak menjadi cemas, takut, sedih, dan timbul perasaan tidak nyaman lainnya. Penelitian membuktikan bahwa hospitalisasi anak dapat menjadi suatu pengalaman yang menimbulkan trauma baik pada anak maupun orang tua sehingga menimbulkan reaksi tertentu yang akan sangat berdampak pada kerja sama anak dan orang tua dalam perawatan anak selama di rumah sakit. (Supartini, 2004) Akhirnya, orientasi pelayanan keperawatan anak berubah yang semula orang tua dilarang untuk mengunjungi anak menjadi rooming in, yaitu orang tua boleh tinggal bersama anaknya di rumah sakit selama 24 jam. Selain itu, mainan boleh di bawa ke rumah sakit, dan penting untuk perawat atau tenaga kesehatan mempersiapkan anak dan orang tuanya sebelum dirawat di rumah sakit. (Supartini, 2004) Berdasarkan penelitian yang dilakukan oleh Mahanani, anak usia prasekolah dan usia sekolah rentan terkena penyakit, sehingga banyak anak pada usia tersebut yang harus dirawat di 
rumah sakit dan menyebabkan populasi anak yang dirawat di rumah sakit mengalami peningkatan yang sangat drastis. Di Indonesia 30\% dari 180 anak antara 3 sampai 12 tahun mempunyai pengalaman dengan rumah sakit. Rata-rata anak mendapat perawatan selama enam hari. Selain membutuhkan perawatan yang spesial dibanding pasien lain, anak sakit juga mempunyai keistimewaan dan karakteristik tersendiri karena anak-anak bukanlah miniatur dari orang dewasa atau dewasa kecil. Waktu yang dibutuhkan untuk merawat penderita anak-anak $20-45 \%$ lebih banyak dari pada waktu untuk merawat orang dewasa. Menurut penelitian yang dilakukan di Paviliun Seruni RSUD Jombang, diperoleh data jumlah usia toddler yang dirawat di Paviliun Seruni dari bulan Mei sampai bulan Oktober 2008, sebanyak 372 dari 1371 jumlah pasien anak yang dirawat. Selama bulan November 2008 terdapat 53 anak usia toddler yang dirawat dan $80 \%$ anak cenderung menunjukkan respon kecemasan, seperti : menangis, rewel, berontak, ingin pulang, menolak tindakan, menjerit, berteriak, dan cenderung minta digendong ibu, ayah atau keluarganya. Musik dapat berfungsi sebagai alat terapi kesehatan. Ketika seseorang mendengarkan musik, gelombang listrik yang ada di otak dapat diperlambat atau dipercepat, dan pada saat yang sama kinerja sistem tubuh pun mengalami perubahan. Musik mampu mengatur hormonhormon yang mempengaruhi stres, serta mampu meningkatkan daya ingat. Musik dan kesehatan memiliki kaitan erat, dan tidak diragukan bahwa dengan mendengarkan musik kesukaan individu maka akan mampu terbawa ke dalam suasana hati yang baik dalam waktu singkat. Oleh karena itu sejumlah rumah sakit di luar negeri mulai menerapkan terapi musik pada pasiennya yang rawat inap. Ketika kita merasa sakit, kita menjadi takut, frustasi, dan marah yang membuat kita menegangkan ratusan otot dalam punggung, dan mendengarkan musik secara teratur membantu tubuh menjadi santai secara fisik dan mental sehingga perlahan dapat menyembuhkan dan mencegah sakit punggung. (Rasyid, 2010) Studi pendahuluan dilakukan melalui observasi pada pasien anak yang dirawat di ruang Teratai Rumah Sakit Dr. Oen Surakarta, buku registrasi pasien masuk dan wawancara dengan perawat yang bertugas di ruangan. Berdasarkan data yang diperoleh jumlah pasien anak usia 3-6 tahun yang dirawat di ruang Teratai pada bulan September berjumlah 43 anak. Hasil wawancara dengan perawat, sebagian besar anak tidak kooperatif dan mengalami kecemasan terhadap tindakan keperawatan yang diberikan ditandai dengan menangis ketika akan dilakukan tindakan medis atau tindakan keperawatan, perawat lebih banyak bekerja sama dengan orang tua saat melakukan tindakan keperawatan, sedangkan di Rumah Sakit Dr. Oen Surakarta belum menyediakan terapi musik dalam pemberian asuhan keperawatan pada anak yang dirawat di Rumah Sakit Dr. Oen Surakarta.

\section{METODE PENELITIAN}

Pada penelitian ini menggunakan metode penelitian quasi eksperimen untuk mengetahui pengaruh terapi musik terhadap penurunan tingkat kecemasan, dengan menggunakan one group pre test dan post test yakni membandingkan tingkat kecemasan sebelum diberi terapi musik dan sesudah diberi terapi musik. Populasi dalam penelitian ini adalah pasien anak yang di rawat di ruang Teratai Rumah Sakit Dr.Oen Surakarta pada bulan November 2013 sampai dengan Januari 2014, sedangkan sampelnya didapatkan 
30 anak. Pengambilan sampel pada penelitian ini dilakukan dengan menggunakan teknik non probability sampling dengan cara purposive sampling dengan kriteria anak usia 3-6 tahun, mengalami perawatan selama 2 hari, mengalami kecemasan akibat hospitalisasi, kesadaran compos mentis, tidak menderita gangguan pendengaran, ditunggu orang tuanya selama sakit, orang tua setuju anaknya menjadi responden.

\section{HASIL PENELITIAN}

Sebelum melakukan penelitian dengan memberikan terapi musik pada anak yang berusia 3-6 tahun yang mengalami kecemasan yang dirawat di Ruang Teratai Rumah Sakit Dr. Oen Surakarta, peneliti melakukan observasi terlebih dahulu untuk mengetahui tingkat kecemasan yang dialami responden dengan menggunakan metode wawancara. Peneliti melakukan wawancara pada responden dan orang tuanya. Ternyata sebagian besar dari responden mengalami kecemasan dikarenakan responden takut saat dilakukan tindakan medis oleh dokter, perawat ataupun petugas kesehatan yang lain. Kemudian peneliti baru memulai terapi musiknya dengan memperdengarkan lagu anak-anak yang berirama ceria dan mengajak responden untuk ikut bernyanyi supaya responden tidak merasa cemas lagi saat dirawat di rumah sakit dan tidak takut lagi saat dokter, perawat ataupun petugas kesehatan lain melakukan tindakan medis. Setelah selesai diberikan terapi musik responden diobservasi lagi dengan menggunakan metode wawancara untuk mengetahui apakah ada penurunan tingkat kecemasan pada anak sebelum dan sesudah diberikan terapi musik.
Tabel 1. Tingkat Kecemasan pada Anak yang Dirawat di Rumah Sakit Dr. Oen Surakarta Sebelum Diberi Terapi Musik

\begin{tabular}{l|c|c}
\hline Tingkat Kecemasan & $\mathrm{F}$ & $\%$ \\
\hline Tidak Ada $(<14)$ & - & - \\
Ringan $(14-20)$ & - & - \\
Sedang $(21-27)$ & 26 & 86,7 \\
Berat $(28-41)$ & 4 & 13,3 \\
Berat Sekali $(42-56)$ & - & - \\
\hline \multicolumn{1}{c|}{ Total } & 30 & 100 \\
\hline
\end{tabular}

Berdasarkan tabel 1 diperoleh informasi bahwa tingkat kecemasan anak sebelum diberikan terapi musik terbanyak berada pada level kecemasan sedang yaitu 26 anak dengan persentase yang diperoleh yaitu $86.7 \%$ dan tingkat kecemasan paling sedikit berada pada level kecemasan berat yaitu 4 anak dengan persentase $13.3 \%$.

Untuk analisa univariat diperoleh mean sebesar 23,63 median 23,00 dan modus 22.

Tabel 2. Distribusi Frekuensi Tingkat Kecemasan pada Anak yang dirawat di Rumah Sakit Dr. Oen Surakarta Setelah Diberi Terapi Musik

\begin{tabular}{l|c|c}
\hline Tingkat Kecemasan & $\mathrm{F}$ & $\%$ \\
\hline Tidak Ada $(<14)$ & 6 & 20 \\
Ringan $(14-20)$ & 20 & 66,7 \\
Sedang $(21-27)$ & 4 & 13,3 \\
Berat $(28-41)$ & - & - \\
Berat Sekali $(42-56)$ & - & - \\
\hline \multicolumn{1}{c}{ Total } & 30 & 100 \\
\hline
\end{tabular}

Dari tabel di atas diperoleh informasi setelah diberikan terapi musik tingkat kecemasan terbanyak berada pada level kecemasan ringan yaitu 20 anak dengan persentase $66.7 \%$ dan kecemasan paling sedikit berada pada level kecemasan sedang yaitu 4 anak dengan persentase $13.3 \%$. Untuk analisa univariat diperoleh mean sebesar 15,43 median 14,50 dan modus 14 . 
Tabel 3. Distribusi Frekuensi Penurunan Tingkat Kecemasan pada Anak yang Dirawat di Rumah Sakit Dr. Oen Surakarta Sebelum dan Setelah Diberi Terapi Musik

\begin{tabular}{c|c|c}
\hline $\begin{array}{c}\text { PenurunanTingkat } \\
\text { Kecemasan }\end{array}$ & $\mathrm{F}$ & $\%$ \\
\hline $1-5$ & 4 & 13,3 \\
$6-10$ & 22 & 73,4 \\
$11-15$ & 4 & 13,3 \\
\hline Total & 30 & 100 \\
\hline
\end{tabular}

Berdasarkan hasil uji dengan Dependent Paired Sample T-test program SPSS versi 18.0 dengan $\alpha$ $=5 \%(0.05)$ diperoleh $p$ value sebesar 0.00 . Sehingga $p<0.05$, yang artinya bahwa ada pengaruh terapi musik terhadap penurunan tingkat kecemasan pada anak yang dirawat di Ruang Teratai Rumah Sakit Dr. Oen Surakarta.

\section{PEMBAHASAN}

Dari hasil distribusi frekuensi tingkat kecemasan pada anak yang dirawat di Rumah Sakit Dr. Oen Surakarta sebelum diberi terapi musik diperoleh data sebagian besar anak mengalami kecemasan sedang dengan rentang nilai (21-27) sebanyak 26 responden dengan persentase $86.7 \%$. Menurut teori yang dikemukakan oleh Suliswati, et al. (2005), kecemasan pada level sedang ditandai dengan terjadinya penyempitan lapang persepsi, dapat melakukan sesuatu dengan arahan orang lain. Sedangkan kecemasan paling sedikit berada pada level berat dengan rentang nilai (28-41) sebanyak 4 responden dengan persentase $13.3 \%$. Kecemasan berat ditandai dengan lapang persepsi individu sangat sempit pusat perhatiannya pada detil kecil (spesifik) dan tidak dapat berpikir tentang hal-hal lain, seluruh perilaku dimaksudkan untuk mengurangi kecemasan dan perlu banyak perintah/arahan untuk terfokus pada area lain. Sedangkan hasil distribusi frekuensi tingkat kecemasan setelah diberi terapi musik ada penurunan tingkat kecemasan dari kategori tingkat kecemasan berat dengan rentang nilai (28-41) menjadi tingkat kecemasan sedang dengan rentang nilai (21-27) sebanyak 4 responden dengan persentase $13.3 \%$, dari tingkat kecemasan sedang dengan rentang nilai (21-27) menjadi tingkat kecemasan ringan dengan rentang nilai (14-20) sebanyak 20 responden dengan persentase $66.7 \%$, dan dari tingkat kecemasan sedang dengan rentang nilai (21-27) menjadi tidak ada kecemasan dengan rentang nilai $(<14)$ sebanyak 6 responden dengan persentase $20 \%$. Dari hasil penelitian pengaruh terapi musik terhadap penurunan tingkat kecemasan pada anak yang dirawat di Ruang Teratai Rumah Sakit Dr. Oen Surakarta diperoleh hasil uji dengan Dependent Paired Sample $T$-test program SPSS versi 18.0 dengan $\alpha=5 \%(0.05)$ diperoleh $p$ value sebesar 0.00 . Sehingga $p<$ 0.05 , yang berarti $\mathrm{Ho}$ ditolak dan $\mathrm{H}_{\mathrm{a}}$ diterima sehingga dapat ditarik kesimpulan bahwa ada pengaruh terapi musik terhadap penurunan tingkat kecemasan pada anak yang dirawat di Ruang Teratai Rumah Sakit Dr. Oen Surakarta. Dari penelitian ini, didapatkan hasil bahwa ada pengaruh terapi musik terhadap penurunan tingkat kecemasan pada anak yang dirawat di Ruang Teratai Rumah Sakit Dr. Oen Surakarta. Hal tersebut dapat terjadi karena anak yang mengalami kecemasan saat dirawat di rumah sakit setelah diberi terapi musik selama 15-20 menit menjadi lebih tenang, tidak takut lagi saat perawat ataupun dokter datang untuk memeriksa. Sesuai dengan teori yang dikemukakan oleh Aizid (2011), musik ternyata dapat mengurangi atau menghilangkan keteganganketegangan penderita pada aspek fisik-motorik, sosial-emosional, dan mental-intelegensi. Musik juga dapat menimbulkan reaksi psikologis yang 
dapat mengubah suasana hati dan kondisi emosi, sehingga musik bermanfaat sebagai relaksasi yang dapat menghilangkan stres, mengatasi kecemasan, memperbaiki mood, dan menumbuhkan kesadaran spiritual karena musik ternyata bersifat terapeutik dan dapat menyembuhkan. Faktor lain yang dapat mempengaruhi adanya penurunan tingkat kecemasan pada anak yang dirawat di rumah sakit antara lain karena keluarga selalu menemani responden selama dirawat di rumah sakit sehingga responden tidak merasa sendirian dan menjadi lebih tenang, anak sudah pernah beberapa kali dirawat di rumah sakit atau sudah beberapa hari dirawat di rumah sakit sehingga anak sudah dapat beradaptasi dengan lingkungan rumah sakit dan dengan para tenaga medis. Karena saat peneliti melakukan penelitian di Rumah Sakit Dr. Oen Surakarta lebih banyak pasien yang sudah beberapa hari dirawat disana dengan persentase $60 \%$ dibandingkan dengan pasien baru dengan persentase $40 \%$. Hasil tersebut sama dengan penelitian sebelumnya yang dilakukan oleh Mahanani pada tahun 2013 dengan judul: Durasi Pemberian Terapi Musik Klasik Mozart Terhadap Tingkat Kecemasan pada Anak di RSUD Banyumas. Dengan hasil analisis didapatkan $p$ value sebesar 0.025 , nilai $\mathrm{p}$ value $<\alpha(0.025<0.05)$, sehingga terdapat perbedaan pengaruh durasi pemberian terapi musik klasik Mozart terhadap tingkat kecemasan pada anak yang mengalami hospitalisasi saat dilakukan pemeriksaan tanda-tanda vital di RSUD Banyumas. Sedangkan penelitian yang dilakukan oleh Ghofar pada tahun 2008 dengan judul : Pengaruh Pemberian Terapi Bermain dan Terapi Musik Terhadap Penurunan Respon Kecemasan Hospitalisasi Anak Usia Toddler di RSUD
Jombang. Dengan hasil penelitian menggunakan uji t-test dengan tingkat signifikansi $\alpha=0.012$ menunjukkan bahwa ada pengaruh dari terapi bermain dan mendengarkan terapi musik.

\section{KESIMPULAN}

Berdasarkan hasil penelitian di atas dapat diperoleh kesimpulan bahwa:

1. Dari hasil analisa univariat tingkat kecemasan pada anak yang dirawat di Ruang Teratai Rumah Sakit Dr. Oen Surakarta sebelum diberi terapi musik didapatkan mean 23.63, median 23.00, modus 22. Sedangkan setelah diberi terapi musik didapatkan mean 15.43, median 14.50, modus 14 Sehingga menunjukkan bahwa ada penurunan tingkat kecemasan pada anak yang dirawat di Ruang Teratai Rumah Sakit Dr. Oen Surakarta sebelum dan setelah diberi terapi musik.

2. Dari hasil uji Dependent Paired Sample T-test program SPSS versi 18.0 dengan $\alpha=5 \%(0.05)$ diperoleh hasil $t$ hitung menunjukkan 21.312 dengan $p$ value sebesar 0.00 . Sehingga $p<$ 0.05 , yang berarti bahwa $\mathrm{Ha}$ diterima dan Ho ditolak, sehingga dapat disimpulkan bahwa terdapat pengaruh terapi musik terhadap penurunan tingkat kecemasan pada anak yang dirawat di Ruang Teratai Rumah Sakit Dr. Oen Surakarta.

\section{SARAN}

Berdasarkan penelitian dan pembahasan mengenai pengaruh terapi musik terhadap penurunan tingkat kecemasan pada anak yang dirawat di Rumah Sakit Dr. Oen Surakarta, peneliti ingin menyampaikan saran sebagai berikut :

1. Bagi institusi Rumah Sakit

Bagi institusi Rumah Sakit diharapkan dapat mempertimbangkan untuk diterapkannya 
terapi musik guna menurunkan tingkat kecemasan pada pasien anak selama dirawat di rumah sakit.

2. Bagi Perawat

Perawat dalam mengatasi masalah kecemasan pada anak yang dirawat di rumah sakit bisa memanfaatkan terapi musik dalam memberikan asuhan keperawatan.

3. Bagi orang tua

Bagi orang tua diharapkan dapat mempertimbangkan memberikan terapi musik pada anak yang mengalami kecemasan baik di rumah maupun di rumah sakit.

\section{DAFTAR PUSTAKA}

Aizid, Rizem. Sehat dan Cerdas dengan Terapi Musik. Yogyakarta: Laksana, 2011.

Dinkes Jawa Tengah. Buku Ajar Asuhan Keperawatan Klien Ansietas (Kecemasan). Jawa Tengah: Dinkes, 2004.

Fajar, et al. Statistika untuk Praktisi Kesehatan. Yogyakarta: Graha IImu, 2009.

Hawari, Dadang. Manajemen Stres Cemas dan Depresi. Jakarta: FKUI, 2011.

Hidayat, A Aziz Alimul. Riset Keperawatan dan Teknik Penulisan IImiah. Edisi I. Jakarta: Salemba Medika, 2003.

.Riset Keperawatan dan Teknik Penulisan IImiah. Edisi II. Jakarta: Salemba Medika, 2008.

Metode Penelitian Keperawatan Teknik Analisis
Data. Jakarta: Salemba Medika, 2009.

Notoatmodjo, Soekidjo. Metodologi Penelitian Kesehatan. Jakarta: Rineka Cipta, 2010.

Nursalam, Rekawati Susilaningrum, dan Sri Utami. Asuhan Keperawatan Bayi dan Anak. Edisi I. Jakarta: Salemba Medika, 2005.

Pinel, John P.J. Biopsikologi. Edisi VII. Alih bahasa Helly Prajitno Soetjipto dan Sri Mulyantini Soetjipto. Yogyakarta: Pustaka Pelajar, 2009.

Potter, Patricia A. dan Anne Griffin Perry. Buku Ajar Fundamental Keperawatan. Edisi IV. Alih bahasa Yasmin Asih. Jakarta: EGC, 2005.

Rasyid, Fathur. Cerdaskan Anakmu dengan Musik. Yogyakarta: Diva Press, 2010.

Riwidikdo, Handoko. Statistik untuk Penelitian Kesehatan dengan Aplikasi Program $R$ dan SPSS. Yogyakarta: Pustaka Rihama, 2009.

Suliswati, et al. Konsep Dasar Keperawatan Kesehatan Jiwa. Jakarta: EGC, 2005.

Supartini, Yupi. Buku Ajar Konsep Dasar Keperawatan Anak. Jakarta: EGC, 2004.

\footnotetext{
1 Dosen AKPER Panti Kosala Surakarta

2 Dosen AKPER Panti Kosala Surakarta

3 Mahasiswa AKPER Panti Kosala Surakarta
} 